Article

\title{
The Mediating Role of Employees' Green Motivation between Exploratory Factors and Green Behaviour in the Malaysian Food Industry
}

\author{
Ha Junsheng ${ }^{1,2,3} \mathbb{C}^{\circ}$, Muhammad Mehedi Masud ${ }^{4, *}$, Rulia Akhtar ${ }^{5}$ and Md. Sohel Rana ${ }^{6}(\mathbb{C}$ \\ 1 School of Economics and Management, Xi'an University of Posts and Telecommunications, \\ Xi'an 710061, China; iboiboha@163.com \\ 2 Western Institution for Digital Economy, Xi'an 710121, China \\ 3 Research Center for Digital Economy and Industrial Integration and Innovation, Xi'an 710121, China \\ 4 Department of Development Studies, Faculty of Economics and Administration, University of Malaya, \\ Kuala Lumpur 50603, Malaysia \\ 5 Ungku Aziz Centre for Development Studies, Faculty of Economics and Administration, \\ University of Malaya, Kuala Lumpur 50603, Malaysia; rulia@um.edu.my \\ 6 Department of Business Policy and Strategy, Faculty of Business and Accountancy, University of Malaya, \\ Kuala Lumpur 50603, Malaysia; sohelnaim@gmail.com \\ * Correspondence: mehedi@um.edu.my; Tel.: +6-03-7967-3630
}

Received: 8 November 2019; Accepted: 23 December 2019; Published: 9 January 2020

\begin{abstract}
Global business entities face the challenge of incremental pressures to restructure their strategic alignments and capabilities to be in accordance with the sustainable development initiatives of the United Nations. This study endeavours to investigate the mediating role of employees' green motivations in the relationships of environmental ethics, the institutional environment, and managerial support with the green behaviour of companies in the Malaysian food manufacturing industry. Data were collected using a questionnaire survey completed by 230 respondents to achieve the study objectives. The respondents consisted of CEOs, company managers, marketing managers, human resources department managers, concerned authorities from environmental protection departments, and producers in the Malaysian food manufacturing industry. The study found that environmental ethics, the institutional environment and managerial support play significant roles in motivating employees' green activities within organisations, while employees' green motivation substantially contributes to the green behaviour of the company. This study also revealed that employees' green motivation plays an important mediating role in the relationships of environmental ethics, the institutional environment, and managerial support with the green behaviour of the company. The implications of this study will be important for allowing governments to take instantaneous action for their climate change pledges to the United Nations Framework Convention on Climate Change (UNFCCC) following the Paris Accord of 2015 and the Marrakech Proclamation of 2016.
\end{abstract}

Keywords: environmental ethics; institutional environment; managerial support; employees' green motivation and company's green behaviour

\section{Introduction}

There is a global commitment to mitigating environmental degradation and promoting sustainable development in order to ensure a safe environment and economy for future generations. The integration of green concepts and environmentally friendly approaches over the course of the recent industrial revolution aims to make industry more energy efficient and strict with respect to waste generation. Recently, the greening of industries has been receiving a great deal of emphasis since it facilitates 
the implementation of environmental ethics in the industrial setup. Therefore, companies need to adopt new strategies and proactive mechanisms in order to comply with the global standard of environmentalism. The adoption and rigorous implementation of environmental ethics by companies aims to ensure a high degree of productivity when utilising scarce resources and adopting green innovations and mechanisms in order to reduce environmental costs [1]. Simultaneously, the value of products will be improved, and the costs of resolving environmental impacts will be offset. Ultimately, green innovation ensures the sustainability of companies in the face of intense global competition [2].

The integration of green approaches in this promising sector may equip it with a competitive advantage in regard to global trade. The demand for food products and beverages has been growing rapidly, and the food processing industry has diversified its food products over the years. The industry produces very large amounts of waste and disposes of contaminated water, causing harm to the environment. Therefore, in order to protect the environment, the food industry needs to adopt initiatives that promote environmental conservation [3]. The Malaysian Department of the Environment [4] released environmental performance reports that showed that the food and beverage industry in Malaysia was the leading contributor to water pollution and that the industry only complied with the minimum required level of relevant environmental regulations, which is in contrast to other industries [3]. Meanwhile, this particular industry uses a very large amount of energy, which results in the generation and emission of a very large amount of carbon dioxide [5]. The food industry also produces a great deal of solid waste, mostly in the form of packaging materials, by-products, and domestic waste, thus placing an additional burden on waste management [3]. Consequently, there is interest among Malaysian food companies in responding to environmental impacts to reap a number of benefits by implementing environmental management systems, preferably ISO 14001 EMS [6].

Several studies addressing the environmental issues and industrial practices in the manufacturing industry in Malaysia have been conducted. For example, Zailani et al. [7] identified the association of eco-friendly industrial design and environmental performance; in addition, Green et al. [8] showed the manner in which the supply chain affects operating, environmental, and organisational performance. Subsequently, Ramayah et al. [9] found a significant influence of green practices on the production performance of SMEs. Furthermore, Rusinko [10] studied sustainable manufacturing practices with significant links to competitive manufacturing outcomes. He concluded that manufacturing costs could be significantly reduced through pollution prevention mechanisms. A recent study conducted by Abdul-Rashid et al. [11] discussed product design, development and manufacturing processes in sustainable ways that had thus far been overlooked in the food industry. A recent study showed that the Malaysian food industry accounts for approximately $14 \%$ of the energy consumption in the manufacturing sector [12]. As the food industry, along with agricultural-based industries, increases $\mathrm{CO}_{2}$ emissions and slows down economic growth [13], this study examines the impacts of environmental ethics, the institutional environment and managerial support on employees' green motivation and green behaviour within the food and beverage industry in Malaysia.

\section{Literature Review and Hypothesis Development}

\subsection{Company Environmental Ethics and Employees' Green Motivation}

Environmental ethics emphasise a person's regular customs related to environmental issues and establishes an individual's obligations to effectively respond to environmental impacts [14]. Ethical compliance has six elements to gauge any standard. These elements are "ethics codes, ethics committees, ethics communication systems, ethics officers, ethics training programmes, and disciplinary processes" $[15,16]$. These ethical aspects are often undertaken and applied by corporations from the management level to the operational level to reduce harmful effects on the environment $[17,18]$. Environmental ethics teach human beings moral responsibilities to protect the environment. Therefore, it is a requirement to demark the periphery of activities to make efficient use of resources while keeping environmental impacts in mind [19]. According to Dutta et al. [20], companies have ample 
opportunities to comply with environmental impacts either by altering the means of producing the goods, changing how they source raw materials, or altering the design of the products so that they minimise their greenhouse gas emissions or reduce the harmful impacts of using the products.

The adoption of a green approach improves a company's value in the corporate sector and helps to formalise an ethical framework to implement environmental ethics in the organisational setup [21-24]. Prior to these research works, some scholars argued that the adoption of green approaches in the production process enables an organisation to comply with environmental ethics and gain competitive market advantages in sustainability and profit maximisation [25,26] (Porter 1980, 1981). Further, these advantages become intangible assets for the organisation, which intensify companies' possibilities to form green relationships with other stakeholders [23-27]. Therefore, such assets provide an organisation with the capabilities to not only avoid the troubles and challenges that come with the equipped environmental measures but also improve their organisational image in the corporate world [28].

Environmental ethics positively influence employees' green environmental performances and subsequently contribute to the green human capital development in the organisational setup. This produces two positive consequences, namely, green innovation learning and green innovation performance [28]. In line with this research, when employees possess the knowledge required for green performance, their behaviour related to green performance improves, and the organisation and its employees are influenced and motivated by the positive aspects of environmental ethics.

\subsection{Corporate Social Responsibility, Institutional Environment and Employees' Green Motivation}

Corporate social responsibility (CSR) is defined as a company's strategically significant commitment to reduce its negative impacts on society and the community to maximize positive effects [29]. CSR practices for environmental sustainability are growing and being placed on various corporate agendas. Babiak and Trendafilova [30] argued that environmentally friendly business practices are a component of CSR. Over the years, environmental sustainability has been one of the greatest interests in terms of the market attitude towards CSR [31] and most important concern for investors in the CSR efforts of a company [32]. Therefore, the institutional theory is viewed as a necessary lens to explore CSR [29].

The institutional environment consists of many internal and external factors that influence decisions regarding green adoption in the organisational setup. The institutional environment is made up of the legal framework, interests of the stakeholders, future economic possibilities, etc., and is supported by institutional theory [33]. Cordano and Frieze [34] found that employees' and managers' attitudes and subjective norms regarding the adoption of preventive measures against pollution and environmental impacts are significantly influenced by the institutional environment.

Institutional theory explains an organisation's external environment, which demonstrates a wide range of social structures that include schemes, rules, norms and routines [35]. The study of Zucker [36] showed that the adoption of green approaches can be facilitated by legislation related to green approaches, continuous pressure from the stakeholders, future economic opportunities, and ethical obligations. Here, 'institution' refers to the formal and informal arrangement that establishes the organisational environment. For example, certain rules, laws and regulations are applied in the formal environmental. Culture, norms and ethics are also integrated into the organisational environment. Hence, any company that needs to make strategic decisions considers both the formal and informal environments in the organisational setup $[35,37,38]$. In line with this, governments are major formal institutions with the authority to promulgate and enforce rules, regulations and necessary legislations. Furthermore, social interactions represent informal interactions that reflect norms, cultures and ethics [39]. The formal and informal environments of an organisation influence the behavioural pattern for adopting green approaches in any organisation. Moreover, the normative and cognitive dimensions of an individual's behaviour also influence green adoption in the organisational environment. For example, social norms, values, beliefs and expectations create social binds and force 
an organisation to welcome green approaches in the organisational environment [40,41]. Similarly, psychological perspectives mirror social constructions and incorporate particular beliefs or long-held axioms about a practice that act as the basis for the goals a certain establishment aims to accomplish [35]. Therefore, the behavioural pattern of an individual or organisation based on both normative and cognitive perspectives reflects the institutional environment.

Shu et al. [39] proposed three interventions of the institutional environment in the context of green product process innovation. First, firms must identify the relevant environmental issues that cause adverse impacts and further convince the stakeholders of the need to mitigate such impacts through any innovative approach, such as being green $[2,42,43]$. Second, firms must observe the existing government policies, responses of consumers and overall public benefits, such as economic and health benefits [44]. Last, firms should review the operational processes, manufacturing practices, supply chain procedures, and decision-making activities pertinent to product innovation, design and the product life cycle $[2,45]$. The enforcement of and compliance with environmental protection rules and regulations in any organisational setup influence employees' motivational patterns, which further facilitates green behaviour in the organisation. In this regard, efforts should be made to develop environmentally friendly food products complying with environmental rules and regulations, which will influence employees to shape the company's behaviour to produce biodegradable and recyclable products [46].

\subsection{Managerial Support and Employees' Green Motivation}

Much of the literature identifies the motivational drivers of an individual to engage in pro-environmental behaviour at the household level [47-49], while studies on motivating employees at the workplace to engage in pro-environmental behaviour are hardly found. Many scholars have suggested that offering rewards (e.g., tax exemptions, profit sharing, or nonmonetary rewards such as recognition or praise) will motivate employees to engage in environmentally friendly behaviour [50-55]. Therefore, management should design reward systems to reinforce and encourage employees to engage in pro-environmental behaviour [50,56]. However, some scholars have found that the use of a culture of rewards, promotions or penalties to enhance the motivation of employees to engage in pro-environmental behaviour is an ineffective tool to ensure the promotion of greener behaviour [57]. The study of Lamm et al. [58] found that general organisational support significantly contributes to organisations' behaviour towards green promotion. Prior to this study, some scholars suggested that the cultural development of promoting environmental values and pro-environmental behaviour is greatly influenced by the organisation's management [59,60]. Robertson and Barling [61] found that a leader's pro-environmental behaviour significantly influences the employees in the organisation. These researchers also determined that the leader must possess transformational leadership qualities to transfer his or her pro-environmental behaviour to employees. A leader also feels that the environmental values must be shared with his or her fellow employees so that they can achieve pro-environmental behaviour together. The leader will also help employees understand environmental issues. The leader should establish a very candid relationship with his or her employees to implement pro-environmental behaviour in the organisation.

\subsection{Employees' Green Motivation and the Green Behaviour of the Company}

For any organisational environment, employees are the drivers of all productive practices. For example, employees have active roles from the manufacturing to the marketing of a product. To date, much of the scholarly studies have addressed employees' physical and psychological states, including their motivational states. The management of any organisation has to perform proficiently to deal with employees' motivational factors. When employees become motivated to welcome green approaches in the organisational setup, that particular firm gains a competitive market advantage [62]. Afterwards, Ho et al. [63] found that when priority is given to innovative and creative management, the employees of the organisation will be more willing to adopt green approaches in the organisation. 
The understanding of a strong commitment by the employees about the organisation will motivate them to shape their behaviour according to the organisation's goals, values, sustainability and greening initiatives [64].

Further, employees' motivation towards environmental behaviour in a company is influenced by factors such as their concerns about the environment, likelihood of organisational support for employees, initiatives and efforts to achieve environmental goals, a positive commitment to the organisation, perceived organisational support for employees' environmental efforts, affective organisational commitment, organisational social responsibilities related to environmental behaviour, and the total amount of time they spend on the organisation [65]. Concern for the environment among the management will facilitate the adoption of green approaches in the organisational setting and is an effective approach to enhance the performance of firms and secure a competitive advantage [66]. Similarly, Dibrell et al. [66] stated that concern for the environment among the top management has become a part of the culture in many organisations that broadens opportunities for the organisation since the top management monitors customers' perceptions and competitors' strategic initiatives related to green aspects. Robertson and Barling [61] noted that transformational leadership and a conducive workplace trigger pro-environmental behaviour, which is due to employees' harmonious environmental interests. The authors further found that leaders' descriptive norms, leadership and pro-environmental behaviour play key roles in adopting green approaches in the organisation.

Furthermore, there are different types of motivational factors, which could be mainly divided into the two factors of intrinsic and extrinsic motivation, that underlie the theory of consumption values. This theory is widely used by researchers, particularly to motivate consumers to buy or not buy a specific product [67]. Zailani, et al. [68] applied this theory to identify the key factors that influence consumers' willingness to pay for biofuels. Wojewnik-Filipkowska et al. [69] included various factors of consumption theory, namely, functional, conditional, emotional and social values, as motivators for their infrastructure project. However, there is a lack of studies that have applied the theory of consumption values to employees' motivation for green behaviour.

The theory of planned behaviour developed by Aizen [70] has been applied to determine how the attitudes of managers influence the environmental decision-making process. Some studies have shown that the environmental behaviour of employees is strongly influenced by their intention to gain green knowledge and their daily green behavioural practices in the organisation [71,72]. Chou [73] used two-level linear hierarchical models that included factors at the individual and group levels that significantly reflect employees' environmental beliefs and behaviour. The author found that green organisations had a direct moderating relationship with individual environmental norms since they directly stimulate employees' behaviour related to the environment, whereas individual beliefs towards the environment indirectly influenced employees' behaviour.

\subsection{The Research Framework of the Study}

The above literature review of environmental ethics, the institutional environment, managerial support, and employees' green motivation can be summarised in the research framework shown in Figure 1. The main objectives of this study are to examine the influence of a company's environmental ethics, institutional environment, and managerial support on employees' green motivation and green behaviour in the Malaysian food and beverage industry. This study also explores whether employees' green motivation has a mediating effect on the relationship between environmental ethics and green behaviour in the industry. 


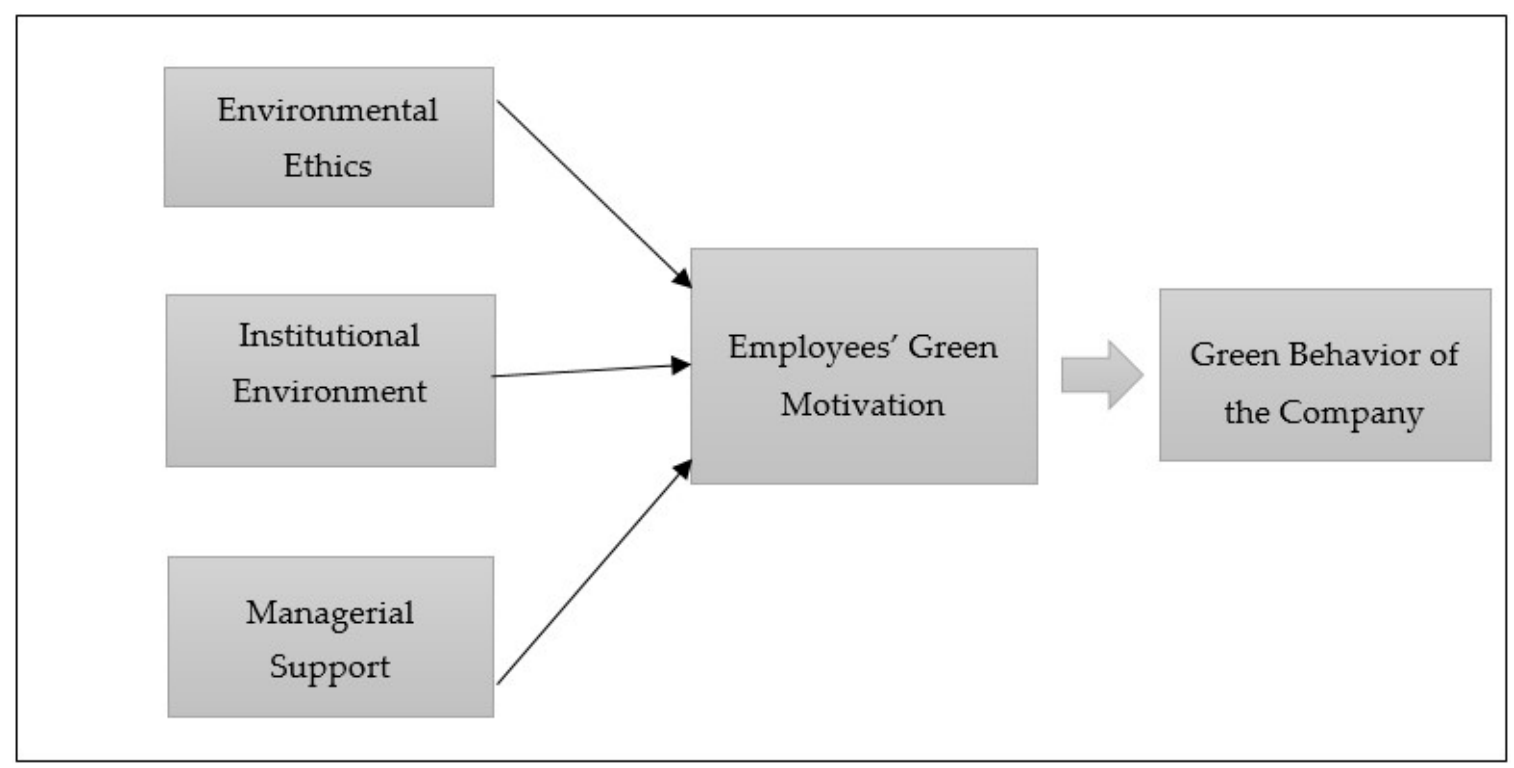

Figure 1. Proposed conceptual model.

\section{Methodology and Measurement}

\subsection{Data Collection and Sample Size}

Data were collected from the Malaysian food manufacturing industry to obtain empirical evidence. The target sample was drawn from "Bursa Malaysia Food and Beverages Companies". The sampled companies were provided detailed information about this study's objectives before disseminating the questionnaire to obtain the highest possible response rate to the survey. The questionnaire was designed and developed based on past literature. Before commencing the data collection, the researchers assessed the content validity of the questionnaire by asking several experts to improve the readability, comprehensibility and clarity of the questionnaire. Then, the questionnaire was disseminated to the 100 targeted food manufacturing industries. The study distributed a total of 500 questionnaires via email, and 230 completed questionnaires were returned, for a response rate of $44 \%$. The target respondents were the CEOs, company managers, marketing managers, human resource or R\&D managers, environmental protection department managers, and production managers from the respective Malaysian food and beverages companies. The respondents were requested to email back the completed questionnaire in no more than two weeks.

\subsection{Definition and Measurements of the Constructs}

The items of the questionnaire were measured using a 5-point Likert scale ranging from 1 to 5 , which represented strong disagreement to strong agreement, respectively. The questionnaire had five parts. The first part collected descriptive data including the number of employees, the establishment year of the business and the industry sector. The other parts of the questionnaire collected information on the company's environmental ethics, institutional environment and managerial support and employees' green motivation and green behaviour in the company. These constructs are defined as follows.

\subsubsection{Environmental Ethics}

Environmental ethics were assessed with five questions measured with a 5-point Likert scale from 1 to 5 . All items were adopted from [23] and shown in Table 1. 


\subsubsection{Institutional Environment}

The institutional environment dimensions were evaluated with a set of items with a scale from 1 to 5 for respondents to indicate the level of agreement and disagreement. Dimensions such as regulatory, normative and cognitive were measured to determine the influence of the institutional environment. The specific items were developed based on institutional perspectives following the work of Busenitz et al. [74], Kostova [75] and Parboteeah et al. [76,77], as shown in Table 1.

\subsubsection{Managerial Support}

Managerial support was measured using five items, as in the study of Craig and Dibrell [78], and evaluated using a 5-point Likert scale ranging from 1 to 5 (see Table 1). These items were focused on determining an owner or manager's attitudinal tendency to allocate a firm's resources to its operational efforts and to environmental approaches to protect the natural environment [79]. One study [80] identified that the owner or manager possesses a strong positive attitude towards the natural environment in regard to a higher composite score.

\subsubsection{Employees' Green Motivation}

The measurement of employees' green motivation included five items that were adopted from [81-83] (see Table 1). All items were evaluated using a 5-point Likert scale ranging from 1 to 5.

\subsubsection{Green Behaviour in the Company}

The measurement of the green behaviour in the company included five items that were adopted from [23]. All items were evaluated using a 5-point Likert scale ranging from 1 to 5.

\section{Empirical Results}

The proposed research model and hypotheses were tested via PLS-SEM, which is a sophisticated statistical tool applied to test and estimate the causal relationships among the studied variables. Environmental ethics, the institutional environment, and management support were the independent variables, while the green motivation of the employees was a mediator between the institutional environment, managerial support and the company's green behaviour. PLS-SEM contains two levels of analysis, namely, the reflective measurement model and the structural model.

\subsection{The Results of the Reflective Measurement Model}

To assess the internal consistency, we examined the factor loadings. All the factor loadings met the suggested value of 0.70 [84], except for MSS1 and MSS2. The low loadings were consequently dropped, as shown in Table 1.

Table 1. Outer loadings of the measurement model.

\begin{tabular}{ccc}
\hline No & Items of the Constructs & Outer Loadings \\
\hline EB1 & The company effectively reduces its emission of hazardous substances \\
or waste & 0.903 \\
\hline EB2 & The company reduces its consumption of water, electricity, coal, or oil & 0.916 \\
\hline EB3 & The company reduces its use of raw materials & 0.901 \\
\hline EB4 & The company recycles waste and emissions so that they can be treated \\
and re-used & 0.805 \\
\hline EB5 & The company maintains the ISO 14001 standards and an environmental \\
management system (EMS) & 0.766 \\
\hline
\end{tabular}


Table 1. Cont.

\begin{tabular}{|c|c|c|}
\hline No & Items of the Constructs & Outer Loadings \\
\hline EE1 & The company has clear and concrete environmental policies & 0.749 \\
\hline EE2 & $\begin{array}{l}\text { The company's budget planning includes environmental investment or } \\
\text { procurement concerns }\end{array}$ & 0.879 \\
\hline EE3 & $\begin{array}{l}\text { The company has integrated its environmental plan, vision, or mission } \\
\text { into its marketing events and culture }\end{array}$ & 0.807 \\
\hline EE4 & $\begin{array}{l}\text { The company's business operations have positive impacts on the } \\
\text { environment that meet and even exceed the legal, ethical, and public } \\
\text { expectations }\end{array}$ & 0.873 \\
\hline EE5 & $\begin{array}{l}\text { The company's environmental programme includes sharing, learning, } \\
\text { and exchanging environmental concepts, information, and knowledge }\end{array}$ & 0.891 \\
\hline EM1 & $\begin{array}{c}\text { Employees are encouraged by the top management to engage in } \\
\text { environmental improvement }\end{array}$ & 0.864 \\
\hline EM2 & Incentives or reward are given to encourage environmental behaviour & 0.878 \\
\hline EM3 & $\begin{array}{l}\text { Engagement workshops or forums are provided for staff to improve } \\
\text { their environmental behaviour }\end{array}$ & 0.883 \\
\hline EM4 & $\begin{array}{c}\text { The company empowers employees to be involved in the improvement } \\
\text { of the environment }\end{array}$ & 0.867 \\
\hline EM5 & $\begin{array}{l}\text { Sufficient training is provided to employeesso that they can participate } \\
\text { in environmental improvement efforts. }\end{array}$ & 0.700 \\
\hline IE1 & Strict enforcement of laws and regulations & 0.869 \\
\hline IE2 & Government recognition for good practices & 0.911 \\
\hline IE3 & Knowledge sharing in the local business community & 0.927 \\
\hline IE4 & Concern for environmental issues & 0.773 \\
\hline IE5 & Encouragement from business associations & 0.815 \\
\hline MSS1 & The business needs to spend more resources on the environment & 0.630 \\
\hline MSS2 & Resources should be devoted to the environment & 0.698 \\
\hline MSS3 & Environmental protection is a part of the bottom-line & 0.794 \\
\hline MSS4 & Business leaders are environment leaders & 0.832 \\
\hline MSS5 & The environment should be protected at all costs & 0.764 \\
\hline
\end{tabular}

Note: $\mathrm{EB}$ = green behaviour; $\mathrm{EE}$ = environmental ethics; $\mathrm{EM}=$ employees' green motivation; IE = institutional environment; and MSS = managerial support.

The reflective measurement model assesses "convergent validity" and "discriminant validity". Convergent validity is "the degree to which indicators of a specific construct converge or share a high proportion of variance in common" [84]. To assess the convergent validity, the composite reliability (CR) and average variance extracted (AVE) were calculated, as suggested by Hair et al. [85]. Table 2 indicates that the CR and AVE values exceed the cut-off points of 0.70 and 0.50 , respectively, as recommended by Hair et al. [85]. This confirms reliability and convergent validity of the constructs.

Table 2. Construct reliability and validity.

\begin{tabular}{ccccc}
\hline & Cronbach's Alpha & rho_A & Composite Reliability & $\begin{array}{c}\text { Average Variance } \\
\text { Extracted (AVE) }\end{array}$ \\
\hline Employee Green Motivation & 0.895 & 0.902 & 0.923 & 0.707 \\
Environmental Behaviour & 0.912 & 0.936 & 0.934 & 0.740 \\
Environmental Ethics & 0.896 & 0.901 & 0.924 & 0.708 \\
Institutional Environment & 0.911 & 0.911 & 0.934 & 0.741 \\
Managerial Support & 0.800 & 0.816 & 0.862 & 0.558 \\
\hline
\end{tabular}


To test the discriminant validity, three methods were employed. First, according to Fornell and Larcker [86], "the average variance shared between each construct, and its measurements should be greater than the variance shared between the construct and other constructs". The results showed that all constructs achieved acceptable "discriminant validity" since the square root of the AVE (diagonal) is greater than the correlations (off-diagonal) for all constructs (see Table 3) [87].

Table 3. Discriminant validity using the Fornell-Larcker criterion.

\begin{tabular}{cccccc}
\hline & $\begin{array}{c}\text { Employee Green } \\
\text { Motivation }\end{array}$ & $\begin{array}{c}\text { Environmental } \\
\text { Behaviour }\end{array}$ & $\begin{array}{c}\text { Institutional } \\
\text { Environment }\end{array}$ & $\begin{array}{c}\text { Managerial } \\
\text { Support }\end{array}$ & $\begin{array}{c}\text { Employee Green } \\
\text { Motivation }\end{array}$ \\
\hline $\begin{array}{c}\text { Employees' Green } \\
\text { Motivation }\end{array}$ & 0.841 & & & & \\
\hline $\begin{array}{c}\text { Environmental } \\
\text { Behaviour }\end{array}$ & 0.455 & 0.860 & & & \\
\hline $\begin{array}{c}\text { Environmental } \\
\text { Ethics }\end{array}$ & 0.706 & 0.331 & 0.842 & 0.861 & 0.747 \\
\hline $\begin{array}{c}\text { Institutional } \\
\text { Environment }\end{array}$ & 0.644 & 0.462 & 0.720 & 0.378 & \\
\hline Managerial Support & 0.405 & 0.628 & 0.210 & & \\
\hline
\end{tabular}

The diagonals represent the square root of the average variance extracted (AVE) and the off-diagonals represent the correlations.

Second, the discriminant validity of the model is evaluated by matching "the cross-loadings" among variables (See Table 4). It is crucial to note that each indicator should have a high loading on its construct but low loadings on the other constructs [84]. The results reveal that all items loadings are higher on their own constructs than on other constructs, which confirms the achievement of discriminant validity.

Table 4. Cross-loadings.

\begin{tabular}{cccccc}
\hline & $\begin{array}{c}\text { Employee Green } \\
\text { Motivation }\end{array}$ & $\begin{array}{c}\text { Environmental } \\
\text { Behaviour }\end{array}$ & $\begin{array}{c}\text { Environmental } \\
\text { Ethics }\end{array}$ & $\begin{array}{c}\text { Institutional } \\
\text { Environment }\end{array}$ & $\begin{array}{c}\text { Managerial } \\
\text { Support }\end{array}$ \\
\hline EB1 & 0.375 & 0.903 & 0.363 & 0.45 & 0.509 \\
EB2 & 0.471 & 0.916 & 0.331 & 0.458 & 0.603 \\
EB3 & 0.442 & 0.901 & 0.323 & 0.435 & 0.589 \\
EB4 & 0.255 & 0.805 & 0.239 & 0.348 & 0.55 \\
EB5 & 0.355 & 0.766 & 0.137 & 0.266 & 0.447 \\
EE1 & 0.574 & 0.315 & 0.749 & 0.513 & 0.177 \\
EE2 & 0.595 & 0.201 & 0.879 & 0.55 & 0.152 \\
EE3 & 0.508 & 0.235 & 0.807 & 0.608 & 0.145 \\
EE4 & 0.651 & 0.316 & 0.873 & 0.629 & 0.165 \\
EE5 & 0.625 & 0.318 & 0.891 & 0.721 & 0.241 \\
EM1 & 0.864 & 0.432 & 0.634 & 0.571 & 0.329 \\
EM2 & 0.878 & 0.39 & 0.665 & 0.598 & 0.327 \\
EM3 & 0.883 & 0.36 & 0.609 & 0.543 & 0.375 \\
EM4 & 0.867 & 0.38 & 0.611 & 0.514 & 0.305 \\
EM5 & 0.700 & 0.349 & 0.422 & 0.47 & 0.381 \\
IE1 & 0.539 & 0.335 & 0.65 & 0.869 & 0.219 \\
IE2 & 0.539 & 0.374 & 0.673 & 0.911 & 0.26 \\
IE3 & 0.535 & 0.417 & 0.641 & 0.927 & 0.393 \\
IE4 & 0.551 & 0.362 & 0.46 & 0.773 & 0.356 \\
IE5 & 0.592 & 0.485 & 0.661 & 0.815 & 0.387 \\
MSS1 & 0.235 & 0.376 & 0.022 & 0.165 & 0.630 \\
MSS2 & 0.277 & 0.475 & 0.155 & 0.3 & 0.698 \\
MSS3 & 0.354 & 0.423 & 0.197 & 0.259 & 0.794 \\
MSS4 & 0.339 & 0.5 & 0.17 & 0.334 & 0.832 \\
MS55 & 0.289 & 0.581 & 0.212 & 0.341 & 0.764 \\
\hline
\end{tabular}

Note: $\mathrm{EB}$ = green behaviour; $\mathrm{EE}$ = environmental ethics; $\mathrm{EM}$ = employees' green motivation; IE = institutional environment; and MSS = managerial support. 
Third, the Heterotrait-Monotrait ratio (HTMT) technique was applied, which was designed by Henseler, et al. [88] to evaluate "discriminant validity". According to this technique, all the scores exceeded the HTMT criterion $[88,89]$. The result showed that discriminant validity was achieved (see Table 5). In addition to that, the results of the HTMT also showed that the confidence interval did not include one for any of the constructs [90], which also supports the discriminant validity.

Table 5. Heterotrait-Monotrait ratio (HTMT).

\begin{tabular}{ccccc}
\hline & $\begin{array}{c}\text { Employee Green } \\
\text { Motivation }\end{array}$ & $\begin{array}{c}\text { Environmental } \\
\text { Behaviour }\end{array}$ & $\begin{array}{c}\text { Institutional } \\
\text { Environment }\end{array}$ & $\begin{array}{c}\text { Managerial } \\
\text { Support }\end{array}$ \\
\hline Employee Green Motivation & & & & \\
\hline Environmental Behaviour & 0.489 & & & \\
\hline Environmental Ethics & 0.780 & 0.357 & 0.794 & 0.438 \\
\hline Institutional Environment & 0.710 & 0.496 & 0.256 & \\
\hline Managerial Support & 0.480 & 0.739 & & \\
\hline
\end{tabular}

\subsection{Assessment of the Structural Model}

In the assessment of a structural model, it is crucial to initially assess collinearity issues; when the VIF is five or lower [91] or, according to the more stringent criteria by Diamantopoulos and Sigouw [92], 3.3 or lower, a collinearity problem might exist. In this report, the results showed that all the inner VIFs for the independent variables were 2.093, 2.334, and 1.178 for environmental ethics, the institutional environment and managerial support, respectively, which were all less than 5 and 3.3. This confirmed that collinearity did not exist [85].

Table 6 and Figure 2 show the relative importance of the exogenous constructs of environmental ethics, the institutional environment and managerial support in predicting the endogenous construct of employees' green motivation. To see the effects of environmental ethics, the institutional environment and managerial support on employees' green motivation, this study revealed that environmental ethics $(\beta=0.532, p$-value $<0.001)$, the institutional environment $(\beta=0.175, p$-value $<0.001)$ and managerial support $(\beta=0.227, p$-value $<0.001)$ have significant positive influences on employees' green motivation. It also confirmed that environmental ethics has the most influential effect on employees' green motivation. The coefficient of determination $R^{2}$ is a measure of the model's predictive accuracy that denotes the amount of variance in the dependent variable that is described by all of the independent variables linked to it. The $r^{2}$ of 0.58 indicates that $58 \%$ of the total variation in employees' green motivation can be explained by environmental ethics, the institutional environment and managerial support.

To determine the effect size of each variable with respect to the $\mathrm{R}^{2}$, the $f^{2}$ values were calculated. According to Cohen (1988), $f^{2}$ values of $0.35,0.15$, and 0.02 are considered large, medium and small effect sizes, respectively. The $f^{2}(0.322)$ of environmental ethics indicates that it had a moderate effect on the $\mathrm{R}^{2}$ for employees' green motivation. The $f^{2}$ of 0.031 for the institutional environment indicates that it had a small effect on the $\mathrm{R}^{2}$ for employees' green motivation. The $f^{2}$ of 0.104 for managerial support indicated a moderate effect on the $\mathrm{R}^{2}$ for employees' green motivation. Finally, the $Q^{2}$ value of 0.38 , which is more than 0 , indicated that the observed values were well reconstructed and that the model has predictive relevance [93]. 


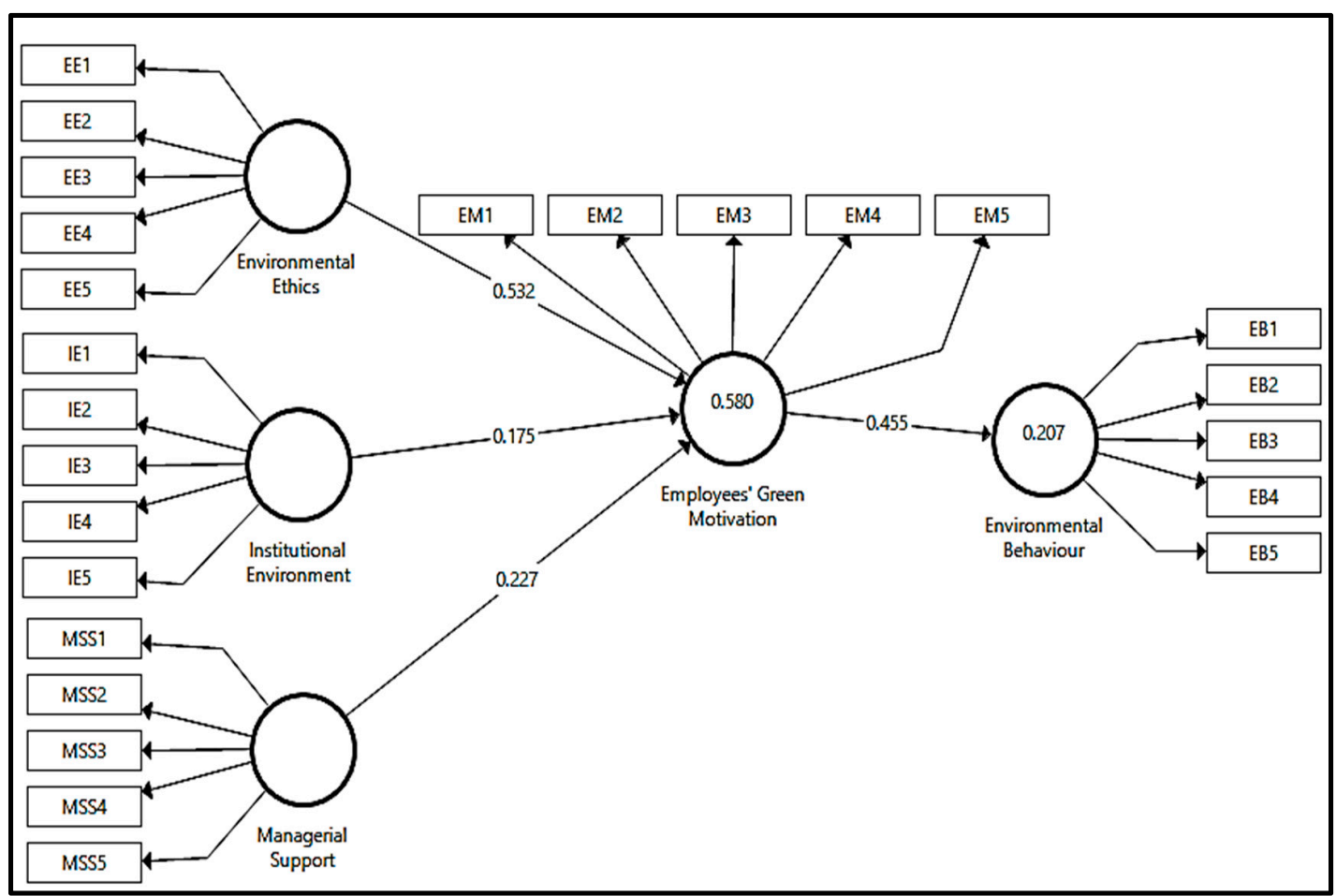

Figure 2. The structural model for Environmental Ethics, the Institutional Environment, Managerial Support, Employee Motivation and Green Behaviour. Note: EB = green behaviour; EE = environmental ethics; $\mathrm{EM}=$ employees' green motivation; $\mathrm{IE}$ = institutional environment; and MSS = managerial support.

Table 6. Path coefficients and hypothesis testing.

\begin{tabular}{ccccccccc}
\hline No & Hypothesis & Coefficient & Std Error & $\boldsymbol{t}$-Value & $\boldsymbol{R}^{\mathbf{2}}$ & $\boldsymbol{f}^{\mathbf{2}}$ & $\mathbf{Q}^{\mathbf{2}}$ & Decision \\
\hline 1 & EE > EM & 0.532 & 0.055 & $9.704^{* * *}$ & & 0.322 & & Supported \\
2 & MSS > EM & 0.227 & 0.065 & $3.471^{* * *}$ & 0.58 & 0.031 & 0.380 & Supported \\
3 & IE > EM & 0.175 & 0.057 & $3.091^{* * *}$ & & 0.104 & & Supported \\
4 & EM > EB & 0.455 & 0.074 & $6.167^{* * *}$ & 0.20 & 0.261 & 0.132 & Supported \\
\hline
\end{tabular}

Note: ${ }^{* * *} p$-value $<0.001 . \mathrm{EB}=$ green behaviour; $\mathrm{EE}=$ environmental ethics; $\mathrm{EM}=$ employees' green motivation; $\mathrm{IE}=$ institutional environment; and MSS = managerial support.

The results also revealed that employees' green motivation had a positive and significant influence on environmental behaviour ( $\beta=0.455, p$-value $<0.001)$. The $r^{2}$ of 0.20 indicated that $20 \%$ of the total variation in the environmental behaviour of the industry can be explained by employees' green motivation. The $f^{2}$ of 0.261 for employees' green motivation indicated a medium effect on the $\mathrm{R}^{2}$ for environmental behaviour. Finally, the $Q^{2}$ value of 0.13 , which was more than 0 , indicated that the observed values were well reconstructed and that the model had predictive relevance.

\subsection{Mediating Effect of Employees' Green Motivation}

In testing the mediating effect of employees' green motivation, this study found that the indirect effects of environmental ethics on employees' green motivation and environmental behaviour ( $\beta=0.242)$, of intuitional environment on employees' green motivation and environmental behaviour ( $\beta=0.080)$, and of managerial support on employees' green motivation and environmental behaviour $(\beta=0.103)$ were statistically significant at the $1 \%$ level with $t$-values of $6.125,2.887$ and 2.704, respectively. The $95 \%$ bias-corrected bootstrap CIs of the indirect effects ([lower limit $(\mathrm{LL})=0.163$, upper limit $(\mathrm{UL})=0.317],[\mathrm{LL}=0.031, \mathrm{UL}=0.139]$, and $[\mathrm{LL}=0.047, \mathrm{UL}=0.193]$ ) did not include 0 , indicating that there was mediation [94]. Thus, we concluded that there were mediating effects on employees' green motivation (see Table 7 and Figure 3). 
Table 7. Hypothesis testing of the mediation.

\begin{tabular}{cccccccc}
\hline \multirow{2}{*}{ Relationship } & \multicolumn{3}{c}{ Confidence Interval (BC) } \\
\cline { 2 - 7 } & Std. Beta & Std. Error & $t$-Value & $\boldsymbol{p}$-Values & LL & UL & Decision \\
\hline EE $>$ EM > EB & 0.242 & 0.04 & 6.125 & 0 & 0.163 & 0.317 & Supported \\
IE $>$ EM $>$ EB & 0.08 & 0.028 & 2.887 & 0.004 & 0.031 & 0.139 & Supported \\
MSS $>$ EM > EV & 0.103 & 0.038 & 2.704 & 0.007 & 0.047 & 0.193 & Supported \\
\hline
\end{tabular}

Note: BC = Bias-Corrected, UL = Upper Level, and LL = Lower Level. EB = green behaviour; EE = environmental ethics; $\mathrm{EM}=$ employees' green motivation; $\mathrm{IE}$ = institutional environment; and MSS = managerial support.

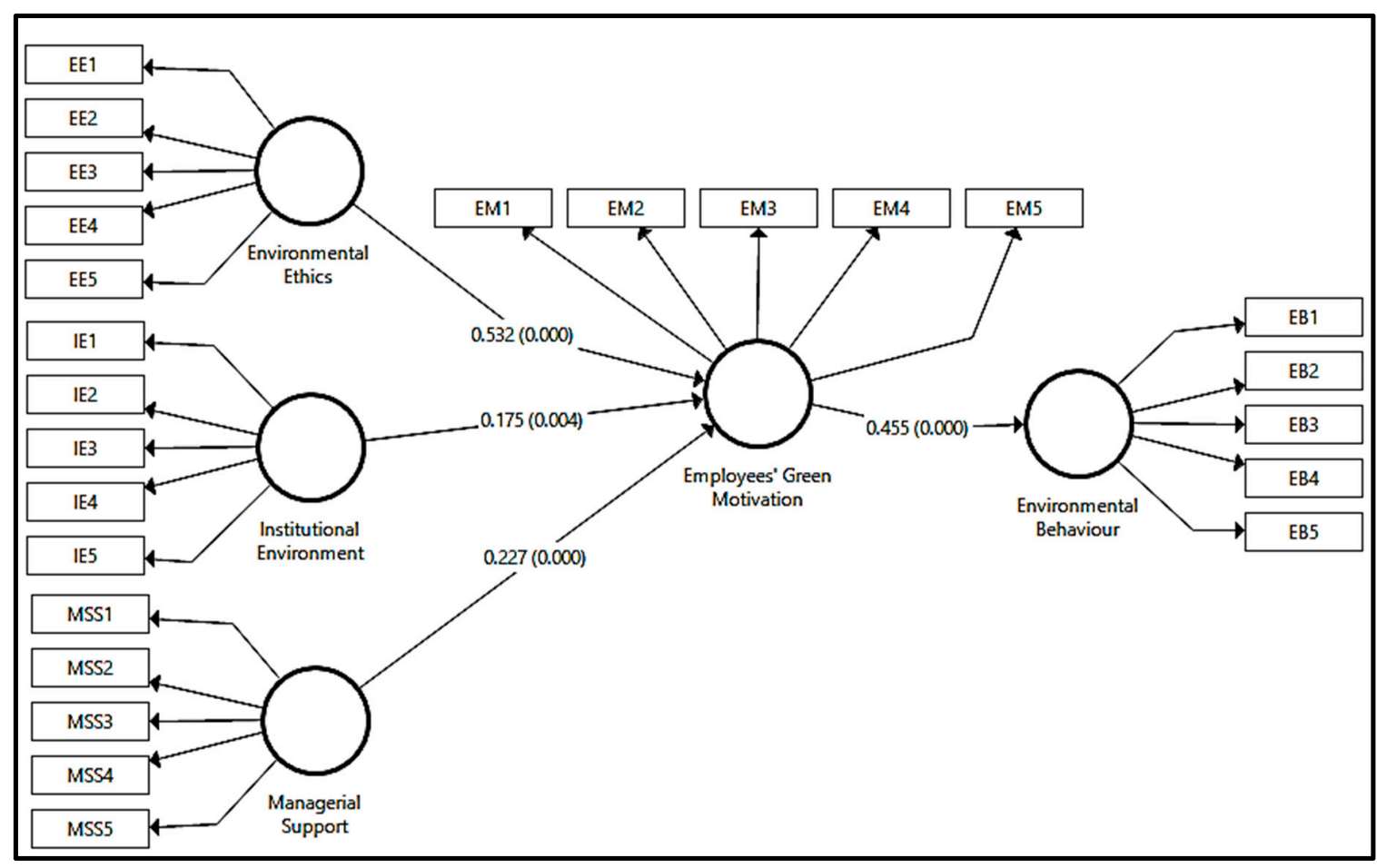

Figure 3. The structural model with mediation (two tails, bootstrapping, 0.05 significance level). Note: $\mathrm{EE}=$ environmental ethics, IE = institutional environment, MSS = managerial support, EMTV = employee motivation to green business, and GBC = green behaviour of the company.

\section{Discussion of the Findings}

The study revealed that an organisation's environmental ethics play a substantial role in motivating employees' green behaviour and prompting green practices within organisations. As stated by Chan [23], organisations' proactive environmental actions are influenced by their environmental ethics. The implementation of these activities relies mostly on a clear vision and mission and plans and strategies for environmental protection. Moreover, with the realisation of the importance of green activities, a company's plan and strategies have to be defined and clearly communicated among all segments of organisations to implement green practices and motivate employees accordingly.

Furthermore, the study revealed that the "institutional environment" has an important influence on employees' green motivation. Poortinga et al. [95] identified that concern for the environment would guide individuals to enact environmentally friendly behaviour. This implies that the institutional environment is of paramount importance to encourage employees' green behaviour. Kostova [75], North [38] and Williamson [96] argued that the enactment and enforcement of the rules imposed in an organisation stimulate certain types of behaviour and restrict other harmful influences. The shared values of social norms greatly influence the behavioural patterns, beliefs and assumptions of any organisation, which follow the direction of social responsibilities and expectations [35,41]. 
The study also revealed that managerial support has a significant impact on employees' green motivation. Managerial support is imperative for employees' green motivation. Eisenberger et al. [97] found that the appreciation of employees' contributions and concerns regarding employees' wellbeing by the organisation prove to be beneficial for the organisation. However, when the staff thinks that the organisation is unable to provide them with adequate support, it becomes detrimental for the organisation [98]. The literature proves that there is a crucial association between managerial support and the green behaviour of employees. Subsequently, this suggests that such a relationship may provide a convincing layout for corporate greening. Previously, Ramus and Steger [99] found that organisational provisions certainly enhance employees' willingness to adopt eco-friendly initiatives in response to environmental degradation. In line with this finding, Lamm et al. [58] identified that green behaviour is greatly influenced by organisational support. The current study and existing literature indicate that the green behaviour in an organisation depends on the extent to which the organisation is supporting and motivating its employees to promote pro-environmental behaviour in the organisation. Although extensive literature has identified the motivational drivers that influence an individual's pro-environmental behaviour at home, there is a dearth of literature about employees' participation in pro-environmental behaviour in the workplace. More importantly, employees' green motivation plays a significant mediating role in the relationships of environmental ethics, the institutional environment, and managerial support with the company's green behaviour. Therefore, the employees' motivation can be enhanced in many ways. Many scholars have suggested that offering rewards, such as tax exemptions, profit sharing, and nonmonetary rewards such as appreciation, will encourage employees' engagement in pro-environmental practices [82].

\section{Conclusions and Policy Implications}

The study examined the impacts of environmental ethics, the institutional environment and managerial support on employees' green motivation and the impacts on a company's green behaviour in the context of the Malaysian food manufacturing industry. There has been a global commitment to mitigate environmental degradation and promote sustainable development to ensure a safe environment and economy for future generations. The integration of green concepts is an environmentally friendly approach in the recent industrial revolution, which will make the industry more energy-efficient and more stringent regarding waste generation. For any manufacturing and service-oriented business, it is critical to remain sustainable in the heat of competition. Hence, every business organisation must reach a certain level of productivity and efficiency while reducing its waste generation and carbon emissions. Malaysia is investing heavily in becoming a developed nation as quick as possible. The role of industry is undeniable in this goal.

Integrating the green concept in industry emphasises the optimisation process through cost minimisation, high business returns and complying with environmental legislation. Additionally, the greening of industrial production processes effectively minimises the adverse impacts on the environment. For example, those industries that adopt green approaches effectively exploit energy, natural resources and raw materials to minimise the risk of hazardous waste generation and promote the reutilisation or recycling of resources by adopting proper waste management strategies to preserve the environment.

Furthermore, the adoption green techniques and technologies in industry provides certain financial and environmental benefits at the global stage. Therefore, green industries help minimise greenhouse gas emissions, which will effectively mitigate the adverse impacts of climate change throughout the globe. To contribute to this global effort, Malaysia stated its willingness to participate in 2009 at the climate change conference at Copenhagen organised by the United Nations, where the former prime minister of Malaysia pledged to reduce the country's carbon emissions by $40 \%$ by 2020 [100]. Recently, the greening of industries has been given much emphasis.

The food and beverage industry consumes a large amount of energy, which results in the generation and emission of a very large amount of carbon dioxide. The food industry also produces a great deal 
of solid waste, mostly from its packaging materials, by-products and domestic waste, which puts an additional burden on waste management.

The food manufacturing industry might play vital role in implementing environmental ethics, which will ensure environmental performance and sustainability and minimise negative environmental impacts. Environmental ethics can be implemented in the Malaysian food manufacturing industry by implementing clear and inclusive environmental policies and providing adequate budgets for environmental protection, which will inspire employees' green motivation and promote corporate green behaviour. In addition, the institutional environment and managerial support play vital roles in motivating employees' green practices within the organisation. Therefore, a company should comply with environmental laws and regulations and share environmental knowledge among its employees to encourage them to address environmental issues. Moreover, managerial support is essential to promoting employees' pro-environmental attitudes and behaviour in the organisation. The Malaysian food manufacturing industry should follow the ISO 14001 standards and adopt an environmental management system (EMS) to ensure its environmental sustainability.

Author Contributions: This is to inform you that H.J. (first author) has contributed substantially to this manuscript by providing his valuable comprehension in designing the manuscript. M.M.M. (corresponding author) has contributed to analyze data and meaningful interpretation of the post analysis. R.A. has contributed to revise the manuscript critically for important intellectual content. M.S.R. has contributed to collect data and data entry. All authors have read and agreed to the published version of the manuscript.

Funding: This research was funded by the Faculty of Economics and Administration (FEA), University of Malaya, grant number (GPF007P-2018) and the APC was funded by School of Economics and Management, Xi'an University of Posts and Telecommunications: Research Project No. 105/205020011.

Conflicts of Interest: The authors declare no conflicts of interest.

\section{References}

1. Chen, Y.S.; Lai, S.B.; Wen, C.T. The influence of green innovation performance on corporate advantage in Taiwan. J. Bus. Ethics 2006, 81, 531-554. [CrossRef]

2. Porter, M.E.; van der Linde, C. Green and competitive: Ending the stalemate. In The Dynamics of the Eco-Efficient Economy: Encironmetal Regulation and Competitive Advantagr; Edward Elgar Publishing, Inc.: Northampton, MA, USA, 1995.

3. Rahim, R.; Raman, A.A.A. Cleaner production implementation in a fruit juice production plant. J. Clean. Prod. 2015, 101, 215-221. [CrossRef]

4. Department of Environment, Malaysia. Environmental Requirements: For Investors. 2010. Available online: http://www.doe.gov.my/eia/wp-content/uploads/2012/03/A-Guide-For-Investors1.pdf (accessed on 10 December 2019).

5. Karakaya, A.; Özilgen, M. Energy utilization and carbon dioxide emission in the fresh, paste, whole-peeled, diced, and juiced tomato production processes. Energy 2011, 36, 5101-5110. [CrossRef]

6. Musaa, H.; Chinniah, M. Malaysian SMEs Development: Future and Challenges on Going Green. Procedia Soc. Behav. Sci. 2016, 224, 254-262. [CrossRef]

7. Zailani, S.; Jeyaraman, K.; Vengadasan, G.; Premkumar, R. Sustainable supply chain management (SSCM) in Malaysia: A survey. Int. J. Prod. Econ. 2012, 140, 330-340. [CrossRef]

8. Green, K.W., Jr.; Zelbst, P.J.; Meacham, J.; Bhadauria, V.S. Green supply chain management practices: Impact on performance. Supply Chain Manag. 2012, 17, 290-305. [CrossRef]

9. Ramayah, T.; Mohamad, O.; Omar, A.; Marimuthu, M.; Leen, J.Y.A. Green manufacturing practices and performance among SMEs: Evidence from a developing nation. In Green Technologies and Business Practices: An IT Approach; IGI Global: Hershey, PA, USA, 2013.

10. Rusinko, C. Green manufacturing: An evaluation of environmentally sustainable manufacturing practices and their impact on competitive outcomes. IEEE Trans. Eng. Manag. 2007, 54, 445-454. [CrossRef]

11. Abdul-Rashid, S.H.; Sakundarini, N.; Raja Ghazilla, R.A.; Thurasamy, R. The impact of sustainable manufacturing practices on sustainability performance: Empirical evidence from Malaysia. Int. J. Oper. Prod. Manag. 2017, 37, 182-204. [CrossRef] 
12. Ali, R.; Daut, I.; Taib, S. A review on existing and future energy sources for electrical power generation in Malaysia. Renew. Sustain. Energy Rev. 2012, 16, 4047-4055. [CrossRef]

13. Palanca-Tan, R.; Dy, T.A.; Tan, A. Relating Carbon Dioxide Emissions with Macroeconomic Variables in the Philippine Setting. Low Carbon Econ. 2016, 7, 12. [CrossRef]

14. Rajalakshmi, S. Sustainable development through environmental ethics. Int. J. Appl. Res. 2016, 2, 464-467.

15. Weaver, G.R.; Trevino, L.K.; Cochran, P.L. Corporate ethics programs as control systems: Influences of executive commitment and environmental factors. Acad. Manag. J. 1999, 42, 41-57.

16. Ahmed, N.U.; Montagno, R.V.; Firenze, R.J. Organizational performance and environmental consciousness: An empirical study. Manag. Decis. 1998, 36, 57-62. [CrossRef]

17. López-Gamero, M.; Molina-Azorín, J.; Claver-Cortés, E. The whole relationship between environmental variables and firm performance: Competitive advantage and firm resources as mediator variables. J. Environ. Manag. 2009, 90, 3110-3121. [CrossRef]

18. Sarkis, J.; Gonzalez-Torre, P.; Adenso-Diaz, B. Stakeholder pressure and the adoption of environmental practices: The mediating effect of training. J. Oper. Manag. 2010, 28, 163-176. [CrossRef]

19. Okafor, N.I.; Ohabuenyi, A.G. An Ethical Approach to Addressing the Environmental Dimension of Sustainable Development Goals (SDGs) in Nigeria. J. Eng. Appl. Sci. 2019, 14, 9903-9908.

20. Dutta, S.K.; Lawson, R.A.; Marcinko, D.J. Enhancing environmental awareness in future business leaders. Int. J. Environ. Sustain. Dev. 2010, 9, 181-193. [CrossRef]

21. Zsolnai, L. Environmental ethics for business sustainability. Int. J. Soc. Econ. 2011, 38, 892-899. [CrossRef]

22. Maon, F.; Lindgreen, A.; Swaen, V. Designing and implementing corporate social responsibility: An integrative framework grounded in theory and practice. J. Bus. Ethics 2009, 87, 71-89. [CrossRef]

23. Chang, C. The Influence of Corporate Environmental Ethics on Competitive Advantage: The Mediation Role of Green Innovation. J. Bus. Ethics 2011, 104, 361-370. [CrossRef]

24. Cornelius, N.; Todres, M.; Janjuha-Jivraj, S.; Woods, A.; Wallace, J. Corporate social responsibility and the social enterprise. J. Bus. Ethics 2008, 81, 355-370. [CrossRef]

25. Porter, M.E. Competitive Advantage: Techniques for Analyzing Industries and Competitors; The Free Press: New York, NY, USA, 1980.

26. Porter, M.E. The contributions of industrial organization to strategic management. Acad. Manag. Rev. 1981, 6, 609-620.

27. Chen, Y.S. The positive effect of green intellectual capital on competitive advantages of firms. J. Bus. Ethics 2008, 77, 271-286. [CrossRef]

28. Chen, Y.S.; Chang, C.H. Greenwash and green trust: The mediation effects of green consumer confusion and green perceived risk. J. Bus. Ethics 2013, 114, 489-500. [CrossRef]

29. Trendafilova, S.; Babiak, K.; Heinze, K. Corporate social responsibility and environmental sustainability: Why professional sport is greening the playing field. Sport Manag. Rev. 2013, 16, 298-313. [CrossRef]

30. Babiak, K.; Trendafilova, S. CSR and environmental responsibility: Motives and pressures to adopt green management practices. Corp. Soc. Responsib. Environ. Manag. 2011, 18, 11-24. [CrossRef]

31. Welford, R.; Chan, C.; Man, M. Priorities for corporate social responsibility: A survey of businesses and their stakeholders. Corp. Soc. Responsib. Environ. Manag. 2008, 15, 52-62. [CrossRef]

32. Kassinis, G.; Vafeas, N. Stakeholder pressures and environmental performance. Acad. Manag. J. 2006, 49, 145-159. [CrossRef]

33. Bansal, P.; Roth, K. Why companies go green: A model of ecological responsiveness. Acad. Manag. J. 2000, 43, 717-736.

34. Cordano, M.; Frieze, I.H. Pollution Reduction Preferences of U.S. Environmental Managers: Applying Ajzen's Theory of Planned Behavior. Acad. Manag. J. 2000, 43, 624-641. [CrossRef]

35. Scott, W.R. Institutions and Organisations; Foundations for Organizational Science: Thousand Oaks, CA, USA, 1995.

36. Zucker, L.G. Institutional theories of organization. Annu. Rev. Sociol. 1987, 13, 443-464. [CrossRef]

37. Yusup, M.Z.; Mahmood, W.H.W.; Salleh, M.R.; Ab Rahman, M.N. The implementation of cleaner production practices from Malaysian manufacturers' perspectives. J. Clean. Prod. 2015, 108, 659-672. [CrossRef]

38. North, D.C. Institutions, Institutional Change and Economic Performance; Cambridge University Press: Cambridge, UK, 1990. 
39. Shu, C.; Zhou, K.Z.; Xiao, Y.; Gao, S. How Green Management Influences Product Innovation in China: The Role of Institutional Benefits. J. Bus. Ethics 2016, 133, 471-485. [CrossRef]

40. Beliveau, B.; Cottril, M.; O'Neill, H. Predicting corporate social responsiveness: A model drawn from three perspectives. J. Bus. Ethics 1994, 13, 731-738. [CrossRef]

41. DuBois, C.L.; Dubois, D.A. Strategic HRM as social design for environmental sustainability in organization. Hum. Resour. Manag. 2012, 51, 799-826. [CrossRef]

42. Xue, F. It looks green: Effects of green visuals in advertising on Chinese consumers' brand perception. J. Int. Consum. Mark. 2014, 26, 75-86. [CrossRef]

43. Buysse, K.; Verbeke, A. Proactive environmental strategies: A stakeholder management perspective. Strateg. Manag. J. 2003, 24, 453-470. [CrossRef]

44. Luo, X.; Du, S. Good Companies Launch More New Products. Available online: https://hbr.org/2012/04/ good-companies-launch-more-new-products (accessed on 15 November 2019).

45. Harris, L.C.; Crane, A. The greening of organizational culture: Management views on the depth, degree and diffusion of change. J. Organ. Chang. Manag. 2002, 15, 214-234. [CrossRef]

46. Leonidou, C.N.; Katsikeas, C.S.; Morgan, N.A. "Greening" the marketing mix: Do firms do it and does it pay off? J. Acad. Mark. Sci. 2013, 41,151-170. [CrossRef]

47. Kollmuss, A.; Agyeman, J. Mind the gap: Why do people act environmentally and what are the barriers to pro-environmental behavior? Environ. Educ. Res. 2002, 8, 239-260. [CrossRef]

48. Diaz-Rainey, I.; Ashton, J.K. Profiling potential green electricity tariff adopters: Green consumerism as an environmental policy tool? Bus. Strategy Environ. 2011, 20, 456-470. [CrossRef]

49. Ozaki, R. Adopting sustainable innovation: What makes consumers sign up to green electricity? Bus. Strategy Environ. 2011, 20, 1-17. [CrossRef]

50. Daily, B.F.; Huang, S.C. Achieving sustainability through attention to human resource factors in environmental management. Int. J. Oper. Prod. Manag. 2001, 21, 1539-1552. [CrossRef]

51. Davies, G.; Smith, H. Natural resources. People Manag. 2007, 8, $26-31$.

52. Govindarajulu, N.; Daily, B.F. Motivating employees for environmental improvement. Ind. Manag. Data Syst. 2004, 104, 364-372. [CrossRef]

53. Jackson, S.E.; Renwick, D.W.; Jabbour, C.J.; Muller-Camen, M. State-of-the-art and future directions for green human resource management: Introduction to the special issue. Ger. J. Hum. Resour. Manag. 2011, 25, $99-116$. [CrossRef]

54. Leitch, J.; Nieves, D.; Burke, G.; Little, M.; Gorin, M. Strategies for Involving Employees. Available online: https://search.proquest.com/openview/9b5d1b7cdbee7ba36dcc1c9c8c474966/1?pq-origsite= gscholar\&cbl=37083 (accessed on 15 November 2019).

55. Patton, K.R.; Daley, D.M. Gainsharing in Zebulon: What do workers want? Public Pers. Manag. 1998, 27, 117-131. [CrossRef]

56. Bragg, T. How to effectively reward and inspire your team. Occup. Hazards 2000, 62, 131.

57. Zibarras, L.; Ballinger, C. Promoting environmental behaviour in the workplace: A survey of UK organisations. In Going Green: The Psychology of Sustainability in the Workplace; City University London: London, UK, 2011; pp. 84-90.

58. Lamm, E.; Tosti-Kharas, J.; Williams, E.G. Read this article, but don't print it: Organizational citizenship behavior toward the environment. Group Organ. Manag. 2013, 38, 163-197. [CrossRef]

59. Ones, D.S.; Dilchert, S. Environmental sustainability at work: A call to action. Ind. Organ. Psychol. 2012, 5, 503-511. [CrossRef]

60. Schein, E.H. The role of the founder in creating organizational culture. Fam. Bus. Rev. 1995, 8, 221-238. [CrossRef]

61. Robertson, J.L.; Barling, J. Greening organizations through leaders' influence on employees' pro-environmental behaviors. J. Organ. Behav. 2013, 34, 176-194. [CrossRef]

62. Ambec, S.; Lanoie, P. Does it pay to be green? A systematic overview. Acad. Manag. Perspect. 2008, $22,45-62$.

63. Ho, Y.-H.; Lin, C.-Y.; Chiang, S.-H. Organizational determinants of green innovation implementation in the logistics industry. Int. J. Organ. Innov. 2009, 2, 3-12.

64. Temminck, E.; Mearns, K.; Fruhen, L. Motivating employees towards sustainable behaviour. Bus. Strategy Environ. 2015, 24, 402-412. [CrossRef] 
65. Ar, I.M. The impact of green product innovation on firm performance and competitive capability: The moderating role of managerial environmental concern. Procedia-Soc. Behav. Sci. 2012, 62, 854-864. [CrossRef]

66. Dibrell, C.; Davis, P.S.; Craig, J. Fueling innovation through information technology in SMEs. J. Small Bus. Manag. 2008, 46, 203-218. [CrossRef]

67. Sheth, J.N.; Newman, B.I.; Gross, B.L. Why we buy what we buy: A theory of consumption values. J. Bus. Res. 1991, 22, 159-170. [CrossRef]

68. Zailani, S.; Iranmanesh, M.; Sean Hyun, S.; Ali, M.H. Applying the theory of consumption values to explain drivers' willingness to pay for biofuels. Sustainability 2019, 11, 668. [CrossRef]

69. Wojewnik-Filipkowska, A.; Dziadkiewicz, A.; Dryl, W.; Dryl, T.; Bęben, R. Obstacles and challenges in applying stakeholder analysis to infrastructure projects. J. Prop. Invest. Financ. 2019. [CrossRef]

70. Ajzen, I. A Theory of Planned Behavior. Organ. Behav. Hum. Decis. Process. 1991, 50, 179-211. [CrossRef]

71. Flannery, B.L.; May, D.R. An Empirical Study of the Effect of Moral Intensity on Environmental Ethical Decision-Making. Acad. Manag. J. 2000, 43, 642-662. [CrossRef]

72. Lal, P.; Lim-Applegate, H.; Scoccimarro, M. The adaptive decision-making process as a tool for integrated natural resource management: Focus, attitudes, and approach. Conserv. Ecol. 2002, 5, 11-26. [CrossRef]

73. Chou, C.J. Hotels' environmental policies and employee personal environmental beliefs: Interactions and outcomes. Tour. Manag. 2014, 40, 436-446. [CrossRef]

74. Busenitz, L.W.; Gomez, C.; Spencer, J.W. Country institutional profiles: Unlocking entrepreneurial phenomena. Acad. Manag. J. 2000, 43, 994-1003.

75. Kostova, T. Country institutional profiles: Concept and measurement. Acad. Manag. Proc. 1997. [CrossRef]

76. Parboteeah, K.; Hoegl, M.; Cullen, J. Ethics and Religion: An Empirical Test of a Multidimensional Model. Available online: http://www.jstor.org/stable/25482150 (accessed on 17 December 2019).

77. Boiral, O.; Paillé, P. Organizational citizenship behaviour for the environment: Measurement and validation. J. Bus. Ethics 2012, 109, 431-445. [CrossRef]

78. Craig, J.; Dibrell, C. The natural environment, innovation, and firm performance: A comparative study. Fam. Bus. Rev. 2006, 19, 275-288. [CrossRef]

79. Pichel, K. Enhancing ecopreneurship through an environmental management system: A longitudinal analysis of factors leading to proactive employee behaviour. In Sustainable Innovation and Entrepreneurship; Wüstenhagen, R., Hamschmidt, J., Sharma, S., Starik, M., Eds.; Edward Elgar Publishing: Northampton, MA, USA, 2008.

80. Roxas, B.; Coetzer, A. Institutional environment, managerial attitudes and environmental sustainability orientation of small firms. J. Bus. Ethics 2012, 111, 461-476. [CrossRef]

81. Dibrell, C.; Craig, J.B.; Hansen, E.N. How managerial attitudes toward the natural environment affect market orientation and innovation. J. Bus. Res. 2011, 64, 401-407. [CrossRef]

82. Zibarras, L.D.; Coan, P. HRM practices used to promote pro-environmental behavior: A UK survey. Int. J. Hum. Resour. Manag. 2015, 26, 2121-2142. [CrossRef]

83. Fernández, E.; Junquera, B.; Ordiz, M. Organizational culture and human resources in the environmental issue: A review of the literature. Int. J. Hum. Resour. Manag. 2003, 14, 634-656. [CrossRef]

84. Hair, J.F., Jr.; Hult, G.T.M.; Ringle, C.; Sarstedt, M. A Primer on Partial Least Squares Structural Equation Modeling (PLS-SEM); SAGE Publications: London, UK, 2016.

85. Hair, J.F.; Black, W.C.; Babin, B.J.; Anderson, R.E. Multivariate Data Analysis, 7th ed.; Prentice Hall: Upper Saddle River, NJ, USA, 2010.

86. Fornell, C.; Larcker, D. Evaluating Structural Equation Models with Unobservable Variables and Measurement Error. J. Mark. Res. 1981, 18, 39-50. [CrossRef]

87. Fornell, C.; Larcker, D.F. Structural Equation Models with Unobservable Variables and Measurement Error: Algebra and Statistics. Available online: https://journals.sagepub.com/doi/abs/10.1177/002224378101800313 (accessed on 21 December 2019).

88. Henseler, J.; Ringle, C.M.; Sarstedt, M. A new criterion for assessing discriminant validity in variance-based structural equation modeling. J. Acad. Mark. Sci. 2015, 43, 115-135. [CrossRef]

89. Gold, A.H.; Malhotra, A.; Segars, A.H. Knowledge management: An organizational capabilities perspective. J. Manag. Inf. Syst. 2001, 18, 185-214. [CrossRef] 
90. Kline, R.B. Principles and Practice of Structural Equation Modeling; Guilford Publications: New York, NY, USA, 2015.

91. Hair, J.F.; Ringle, C.M.; Sarstedt, M. PLS-SEM: Indeed a silver bullet. J. Mark. Theory Pract. 2011, 19, $139-152$. [CrossRef]

92. Diamantopoulos, A.; Siguaw, J.A. Formative versus reflective indicators in organizational measure development: A comparison and empirical illustration. Br. J. Manag. 2006, 17, 263-282. [CrossRef]

93. Fornell, C.G.; Cha, J. Partial least squares. In Advanced Methods of Marketing Research; Bagozzi, R.P., Ed.; Blackwell: Oxford, MI, USA, 1994.

94. Preacher, K.J.; Hayes, A.F. Asymptotic and resampling strategies for assessing and comparing indirect effects in multiple mediator models. Behav. Res. Methods 2008, 40, 879-891. [CrossRef]

95. Poortinga, W.; Steg, L.; Vlek, C. Values, environmental concern, and environmental behavior: A study into household energy use. Environ. Behav. 2004, 36, 70-93. [CrossRef]

96. Williamson, O. Comparative economic organisations: The analysis of discrete structural alternative. Adm. Sci. Q. 1991, 36, 269-296. [CrossRef]

97. Eisenberger, R.; Huntington, R.; Hutchison, S.; Sowa, D. Perceived organizational support. J. Appl. Psychol. 1986, 71, 500-507. [CrossRef]

98. Gibney, M.J.; Vorster, H.H.; Kok, F.J. (Eds.) Introduction to Human Nutrition; Blackwell Science: Oxford, MI, USA, 2002; pp. 100-113.

99. Ramus, C.A.; Steger, U. The roles of supervisory support behaviors and environmental policy in employee "Ecoinitiatives" at leading-edge European companies. Acad. Manag. J. 2000, 43, 605-626.

100. New Straits Times. PM: Malaysia on Course to Reduce Carbon Emissions by 40 Pct by 2020. Available online: https://www.nst.com.my/news/nation/2017/12/310231/pm-malaysia-course-reduce-carbonemissions-40-pct-2020 (accessed on 15 November 2019).

(C) 2020 by the authors. Licensee MDPI, Basel, Switzerland. This article is an open access article distributed under the terms and conditions of the Creative Commons Attribution (CC BY) license (http://creativecommons.org/licenses/by/4.0/). 